Bangladesh J. Plant Taxon. 27(1): 27-35, 2020 (June)

(C) 2020 Bangladesh Association of Plant Taxonomists

\title{
CONTRIBUTION TO THE SYSTEMATIC KNOWLEDGE OF ENDEMIC AUBRIETA PINARDII BOISS. (BRASSICACEAE) FROM TURKEY
}

\author{
Emrah ŞiriN* and Mehmet Cengiz KaraismailoĞLu ${ }^{1}$ \\ Department of Biology, Faculty of Science, Selçuk University, Konya, Turkey \\ Keywords: Anatomy, Chromosome, Cruciferae, Morphology, Pollen.
}

\begin{abstract}
The aim of this study was to document the taxonomical, morphological, anatomical, palynological and cytological characters, and geographical distribution of endemic Aubrieta pinardii Boiss. (Brassicaceae) from Turkey. The description of the taxon was revised as a consequence of comprehensive assessments of many specimens. The surface pictures belonging to seed and pollen of the taxon were obtained by Scanning Electron Microscope. The seed surface ornamentation was rugose. The pollen was radially and isopolar and prolate in forms, with polar axes of $19.52 \pm 0.29 \mu \mathrm{m}$ and equatorial axes of $13.04 \pm 0.22 \mu \mathrm{m}$, with oval outlines in the equatorial axes, and elliptical in the polar axes. They were three-colpate and colpus sizes varied between $12.98 \mu \mathrm{m}$ and $13.29 \mu \mathrm{m}$ in length, and between 1.33 and $2.09 \mu \mathrm{m}$ in width. Also, the anatomical structures of the root, stem and leaf of species were studied. In cytological studies, the chromosome number of species was found as $2 n=16(x=8)$. This was the first work including taxonomical, morphological (macro and micro), anatomical and cytological data of endemic Aubrieta pinardii.
\end{abstract}

\section{Introduction}

The family Brassicaceae has 365 genera and 3250 species worldwide, and it is well-known as a major family having commercial importance (Simpson, 2006; Tekin et al., 2013; Karaismailoğlu, 2017a). Turkey with over 650 species is one of the most diversity centers of the family (Al Shehbaz et al., 2007; Güner et al., 2012). The genus Aubrieta has 22 species in the world. In Turkey, it has 10 species, six of which (A. alshehbazii Dönmez, Uğurlu \& M.A. Koch, A. anamasica Pesmen \& Güner, A. ekimii Yüzb., Al-Shehbaz \& M.A. Koch, A. olympica Boiss., A. pinardii Boiss. and A. vulcanica Hayek \& Siehe) are endemic (Güner et al., 2012; Yüzbaşığlu et al., 2015; Dönmez et al., 2017; Karaismailoğlu 2017a). This endemism percentage (50\%) indicates that Turkey is one of the gene centers of the genus (Karaismailoğlu, 2016, 2017a). Most of the Aubrieta taxa are perennials plants growing on stones in mountainous or subalpine regions between South Europe and Middle Asia (Gustavsson, 1986; Phitos, 2002; Karaismailoğlu, 2016, 2017a; Koch et al., 2017).

The first exhaustive taxonomic research of Aubrieta was given by Boissier (1867). Afterwards, Mattfield (1937) worked on the taxonomical appearance of the genus. Al-Shehbaz (2010) informed the difficulties in determining reliable morphological characteristics that show variation. The taxonomy of Arabideae including genus Aubrieta has been compelling due to excessive similarity in macromorphological characters (Koch et al., 2017).

A number of studies on some Aubrieta taxa, like morphology of some Bulgarian taxa (Ančev and Goranova, 2009), morphology, anatomy and cytology of A. canescens subsp. canescens (Karaismailoğlu, 2016) and molecular data such as plastid matK and chloroplast gene ndhF of $A$. deltoidea (Koch et al., 2001) were conducted previously. Apart from these, there were no systematic studies directly related to the genus. The genus Aubrieta need to be studied in detail, owing to the paucity of information on its taxa.

*Corresponding author, email: emrahsirin@ selcuk.edu.tr

${ }^{1}$ Siirt University, Faculty of Arts and Sciences, Department of Biology, Siirt, Turkey. 
In this study, taxonomical, macromorphological, micromorphological, anatomical, palynological, and cytological characters of endemic Aubrieta pinardii Boiss. have been revealed for the first time, and that have contributed to the systematics of the genus.

\section{Materials and Methods}

Specimens were collected by the second author and housed in the herbarium of the Science Faculty of Selçuk University (KNYA) (Locality: Konya, Beyşehir, Başarakavak crossroads, stony places, $1350 \mathrm{~m}, 11$ April 2018, E. Şirin $708 \mathrm{H}$. Günal). At least ten seeds or anthers for each species were dehydrated in alcohol series $(70 \%, 80 \%, 96 \%$ and 100\%) in SEM analyses for cleaning process. Seeds were coated with gold under ZEISS EVO LS-10 model SEM highvacuum mode for observing their surface at 30X, 1000X and 2000X magnifications. The terminology of micro characteristics was performed according to Stearn (1992) and Koul et al., (2000). In addition, the stereo microscope images of the seeds were photographed with the LEICA DFC295 digital camera attached to the LEICA S8AP0 microscope.

For the anatomical examinations, cross-sections from the root, stem, and leaf were collected using a fully automatic microtome (Thermo Shonda Met Finesse). Later, they were treated through a ethyl alcohol and xylene series and stained with hematoxylin or methylene blue in a dying apparatus (ASC 720 Medite) and covered with Entellan to examine their anatomical structures (Karaismailoğlu, 2015a, 2015b, 2016, 2019). The anatomical characters were observed with utilizing an Olympus CX21FS1 microscope and Kameram Imaging Software.

Primary root meristems obtained by germinating seeds were utilized for chromosomal analyses. The protocol of Karaismailoğlu (2016) was followed with some modifications in preparation of the slides. The root tips were pretreated in 5\% a-bromonaftol solution for $4 \mathrm{~h}$, allowed to stand $24 \mathrm{~h}$ in Carnoy (3:1 = ethyl alcohol:glacial acetic acid), hydrolyzed in $1 \mathrm{~N} \mathrm{HCl}$ for 6-8 $\mathrm{min}$ at $60^{\circ} \mathrm{C}$, and stained with aceto-orcein for $3 \mathrm{~h}$. Eventually, preparations were coated with Entellan to make them permanent. The best metaphase images were photographed with an Olympus CX21FS1 light microscope (Tokyo, Japan) attached to a digital camera.

\section{Results and Discussion}

Taxonomic description: Densely caespitose herbs. Stems 7-11 cm; flowering stems 3-5.5 cm; covered with mixture of stalked pubescent, 3-5-rayed dendroid, simple long setose and forked trichomes. Leaves numerous, similar to each other, shortly petiolate, slightly clasping the stem, narrowly oblanceolate, with one pair of teeth on each side or entire, 14-18 $\times 1-4 \mathrm{~mm}$, obtuse at apex; stalked, 3-6-rayed and densely mixed with stellate, forked and simple bristles on both surface. Racemesclose cluster of 3-6 flowers, densely pubescent. Sepals lanceolate, $8-10 \times 2-3$ $\mathrm{mm}$, pedicellate, pubescent, green outside, glabrous inside, inner sepals saccate, apex acute. Petals violet, 16-18 × 7-9 mm, well-differentiated into an obovate limb and a claw 7-9 mm. Filaments unwinged, white in lower half, violet towards apex; median ones 8-19 mm, lateral 6-7 mm; anthers narrowly elliptic, $0.5-1 \mathrm{~mm}$. Fruit siliquiform, $23-30 \times 1.5-2 \mathrm{~mm}$ (excluding style), mostly straight, compressed parallel to the septum; uniformly pubescent with short-stalked 3-6rayed trichomes, mature valves slightly reticulate-veined; style $2.5-4 \mathrm{~mm}$; stigma capitate, entire. Seeds biseriate, c. 15-20 in each locule, broadly elliptic to broadly oblong, pale brown to black, wingless, surface ornamentation rugose, not mucilaginous when wetted, $1.3-1.7 \times 0.6-0.7 \mathrm{~mm}$ (Figs 1-2).

Pollen morphology: Pollens were radially and isopolar and prolate in forms, with polar axes of $19.52 \pm 0.29 \mu \mathrm{m}$ and equatorial axes of $13.04 \pm 0.22 \mu \mathrm{m}$, with oval outlines in the equatorial axes, and elliptical in the polar axes (amb) (Fig. 3). They were three-colpate. Also, colpus sizes varied between $12.98 \mu \mathrm{m}$ and $13.29 \mu \mathrm{m}$ in length, and between 1.33 and $2.09 \mu \mathrm{m}$ in width. The 
margins were organized. The exine thickness varied between 1.05 and $1.48 \mu \mathrm{m}$, and it was usually thicker in the apertural sections. Additionally the intine thickness ranged from 0.32 to $0.48 \mu \mathrm{m}$. A. pinardii was of coarse reticulate ornamentation type with somewhat meandering muri. The lumina comprised of polygonal or irregular cells; its diameter ranged from 0.48 to $1.52 \mu \mathrm{m}$.
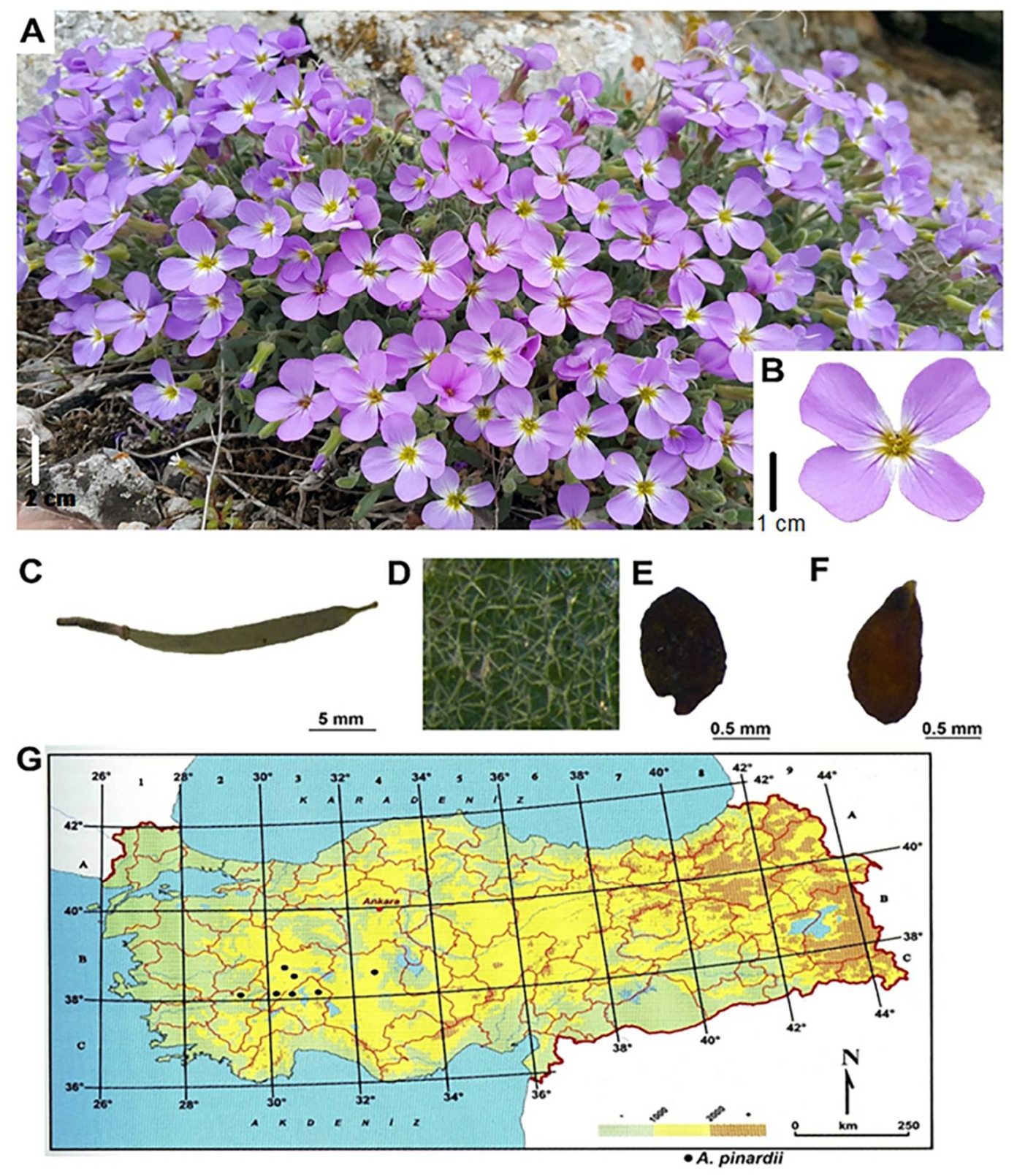

Fig. 1. Aubrieta pinardii. a: Habit, b: a flower, c: a fruit, d: surface of the fruit, e and f: seed, g: distribution map (localities were taken from Dönmez et al. 2017). 

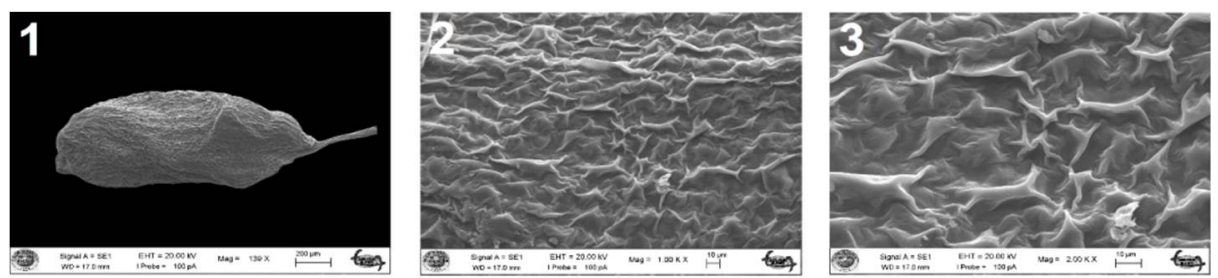

Fig. 2. SEM pictures of $A$. pinardii seeds: 1. Overview, 2 and 3. surface.
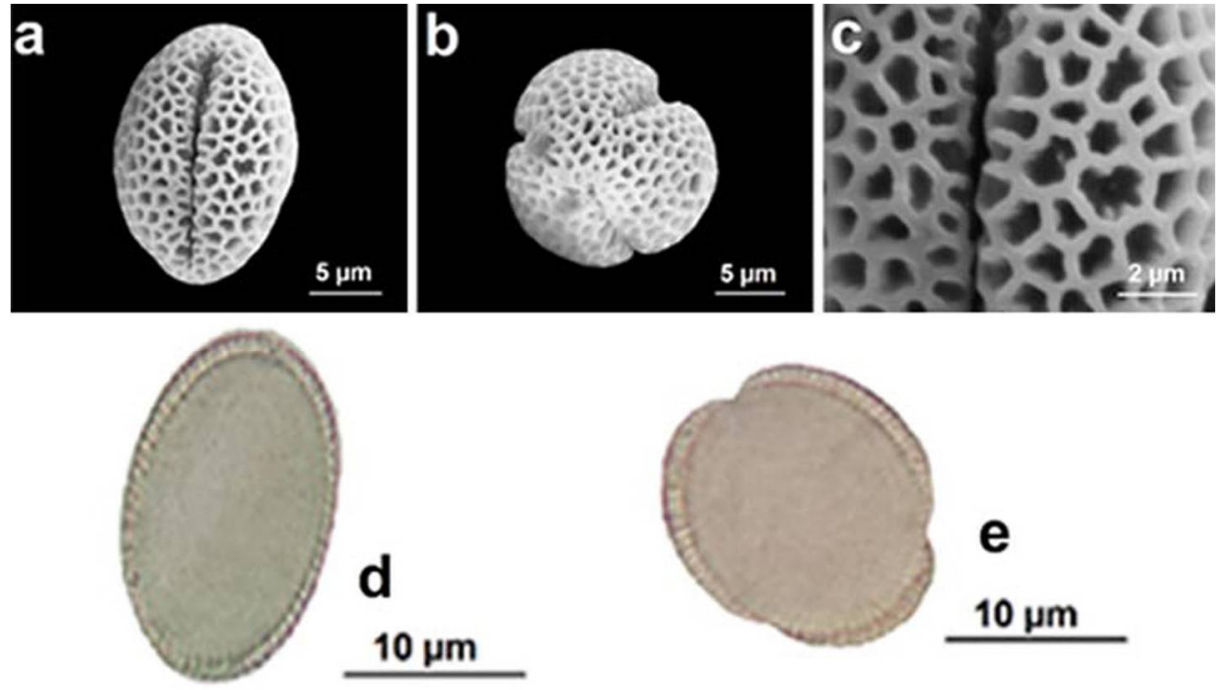

Fig. 3. Pollen morphology of A. pinardii. a: polar axis, b: equatorial axis, c: surface of pollen (SEM), d: polar axis, e: equatorial axis (Light microscope).

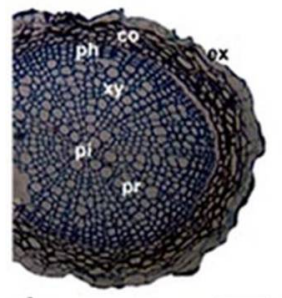

1

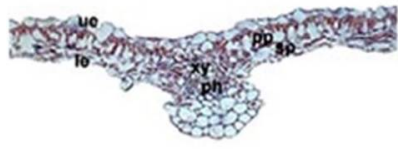

4
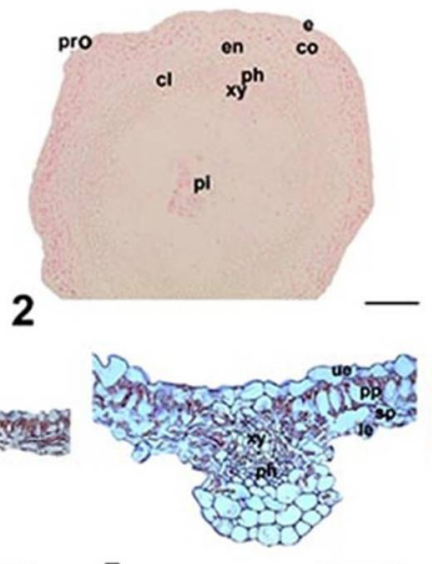

5

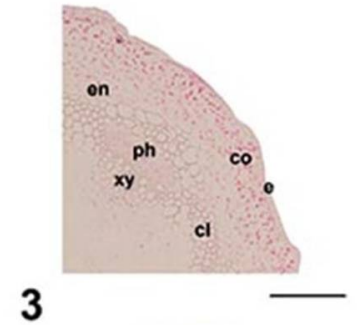

3

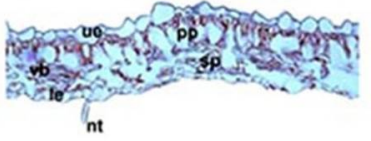

6

Fig. 4. The anatomical structures of A. pinardii. 1: root, 2-3: stem, 4-6: leaf (ex: exodermis, co: cortex, ph: phloem, xy: xylem, pi: pith region, pr: pith ray, e: epidermis, pro: protrusion, en: endodermis, cl: chlorenchyma, ue: upper epidermis, le: lower epidermis, pp: palisade parenchyma, sp: spongy parenchyma, vb: vascular bundle, nt: non-glandular trichome, scale bars $=100 \mu \mathrm{m}$ ). 
Root, stem and leaf anatomy: An exodermis, consisting of flat cells with 1-3 layered was placed on the outermost surface of A. pinardii (Fig. 4). The thickness of this layer ranged from $21.43 \mu \mathrm{m}$ to $50.65 \mu \mathrm{m}$. Under exodermis, cortex contained of multilayer scleranchymatic cells between $15 \mu \mathrm{m}$ and $38 \mu \mathrm{m}$ in diameter. Endodermis layer is not pronounced. The most enclosed space in the roots was shaped by secondary xylem. Pith rays extended from large parenchymatic cells (Fig. 4). The palisade parenchyma in the mesophyll layer covers more space than spongy parenchyma.

In cross-sections of the stem, 1 layered epidermis consisting of flat or rectangular cells was detected in outermost (Figure 4). The dimensions of epidermis cells were recorded as 8-18 $\mu \mathrm{m}$ in length, and 3-6 $\mu \mathrm{m}$ in width. Under the epidermis layer, there was a cortex with 5-9 layered, consisting of ovoid or flat shaped cells. Its thickness was in 70.59 and $81.96 \mu \mathrm{m}$. The xylem and phloem elements were indistinct. The vascular bundle was open collateral type. The vessel member diameter showed variations between 11.72 and $26.08 \mu \mathrm{m}$. Innermost, there was also a layer consisting of large parenchymatous cells (Fig. 4).

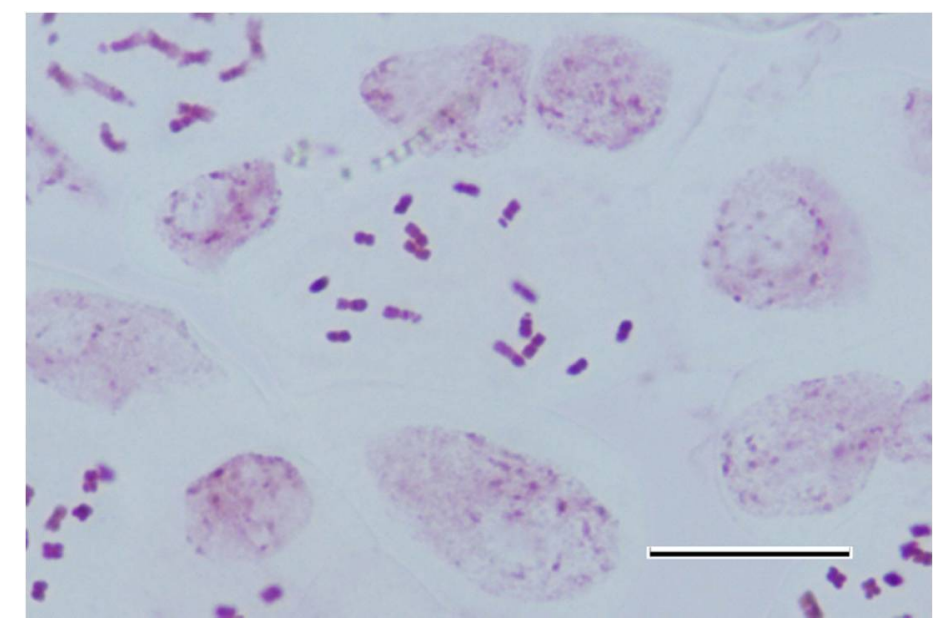

Fig. 5. The chromosomes of A. pinardii in metaphase $(2 n=16)$.

In the abaxial and adaxial surfaces of the leaf, single-layer epidermis cells consisting of irregularly flat or polygonal cells were detected. The leaf was bifacial. The mesophyll layer was noticed as having 2-4 spongy layers and a thickness of 35-55 $\mu \mathrm{m}$, and 1 layered palisade parenchyma with a thickness of $65-85 \mu \mathrm{m}$. The leaves were of collateral vascular bundles, which were surrounded by parenchymatic cells (bundle sheet) (Fig.4).

Cytology: The chromosome number of $A$. pinardii, $2 n=16$, counted in root tips, is also reported and illustrated for the first time (Fig. 5).

Aubrieta is problematic in terms of its systematics, and frequent field examinations are necessary to define the limit of taxa belonging to the genus (Cullen, 1965). Description of $A$. pinardii was very narrow-scope in Flora of Turkey and it has been updated and revised with intensive field works (Table 1). The taxonomic characterization of the species was updated by addition of more characteristics from a significant number of plants taken from the native populations, in comparison with characters in Flora of Turkey (Cullen, 1965). Morphological characters reported for the first time are stem and leaves indumentum and measurements, 
filaments, anthers, style, stigma and seeds features (Table 1). In this study, information on the distribution of Aubrieta pinardii have been provided for the first time.

Table 1. New characters for the examined taxon (A. pinardii) and their comparison with the relevent descriptions in the Flora of Turkey (Cullen, 1965).

\begin{tabular}{|c|c|c|}
\hline Characters & $\begin{array}{l}\text { According to Cullen } \\
\text { (1965) }\end{array}$ & $\begin{array}{l}\text { The obtained outcomes from } \\
\text { this investigation }\end{array}$ \\
\hline Stems $(\mathrm{cm})$ & - & $7-11$ \\
\hline Flowering stems $(\mathrm{cm})$ & - & $3-5.5$ \\
\hline Stem indumentum & - & $\begin{array}{l}\text { pubescent with stalked, 3-5-rayed dendroid, simple long } \\
\text { setose and forked trichomes }\end{array}$ \\
\hline Stem leaves $(\mathrm{mm})$ & - & $14-18 \times 1-4 \mathrm{~mm}$ \\
\hline $\begin{array}{l}\text { Stem leaves } \\
\text { indumentum }\end{array}$ & - & $\begin{array}{l}\text { stalked 3-6-rayed and densely mixed with stellate, } \\
\text { forked and simple bristles }\end{array}$ \\
\hline Sepals & $8-10 \mathrm{~mm}$ & $\begin{array}{l}\text { lanceolate, } 8-10 \times 2-3 \mathrm{~mm} \text {, pubescent, green outside, } \\
\text { glabrous inside, inner sepals saccate, apex acute }\end{array}$ \\
\hline Petals & purple, $18-19 \mathrm{~mm}$ & $\begin{array}{l}\text { violet, } 16-18 \times 7-9 \mathrm{~mm} \text {, well differentiated into an } \\
\text { obovate limb and a claw } 7-9 \mathrm{~mm} \text {. }\end{array}$ \\
\hline Filaments & - & $\begin{array}{l}\text { unwinged, white in lower half, violet towards apex; } \\
\text { median ones 8-19 mm, lateral 6-7 mm }\end{array}$ \\
\hline Anthers & - & narrowly elliptic, $0.5-1 \mathrm{~mm}$ \\
\hline Fruits & $\begin{array}{l}\text { siliquiform, } 22-35 \times \\
2-2.5 \mathrm{~mm} \text {, with an } \\
\text { indumentum of } \\
\text { stellate hairs }\end{array}$ & $\begin{array}{l}\text { siliquiform, } 23-30 \times 1.5-2 \mathrm{~mm} \text { (excluding style), mostly } \\
\text { straight, compressed parallel to the septum; uniformly } \\
\text { pubescent with short-stalked 3-6-rayed trichomes, } \\
\text { mature valves slightly reticulate-veined }\end{array}$ \\
\hline Style-stigma & - & style $2.5-4 \mathrm{~mm}$; stigma capitate, entire \\
\hline Seeds & - & $\begin{array}{l}\text { biseriate, c. } 15-20 \text { in each locule, broadly elliptic to } \\
\text { broadly oblong, pale brown to black, wingless, not } \\
\text { mucilaginous when wetted, } 1.3-1.7 \times 0.6-0.7 \mathrm{~mm}\end{array}$ \\
\hline
\end{tabular}

A. pinardii seems morphologically similar to A. vulcanica and A. parviflora, however, A. pinardii differs from these species by its petal lengths and indumentum of inner sepals (Cullen, 1965), toothed leaves and similar to them stellate hairs on fruits. The results obtained from morphological studies are consistent with description given in the Cullen (1965), Yüzbaşığlu et al. (2015) and Dönmez et al. (2017). Seed coat patterns are used for solving classification problems, establishing evolutionary relationships, elucidating the adaptive significance of the seed coat, and serving as genetic markers for the identification of genotypes in segregating hybrid progenies (El-Naggar, 2005; Bona, 2013; Karaismailoğlu and Erol, 2018; Gabr, 2018; Ozcan and Akinci, 2019). Seed micromorphology of Aubrieta taxa from Turkey was studied before by Yüzbaşıŏlu et al. (2015; A. ekimii) ), Karaismailoğlu (2016; A. canescens subsp. canescens) and Dönmez et al. (2017; A. alshehbazii). Our study is the first report on the seed micromorphology of A. pinardii. The surface ornamentation of species has recorded as rugose, which is commonly noticed in many genera in the family (Murley, 1951; Koul et al., 2000; Zeng et al., 2004; Moazzeni et al., 2007; Karaismailoğlu, 2016, Karaismailoğlu and Erol, 2018).

The data about pollen morphological characters can permit us to better recognize the pragmatism of pollen works in separating the correlated taxa. The pollen shape observed in $A$. 
pinardii is the most common type in its family and is consistent with the findings of Khalik and Maesn Van Der (2002), Mutlu and Erik (2012), and Karaismailoğlu (2017b and 2019). The aperture and exine features of $A$. pinardii were explained as the important standard for the categorization of phylogenetic correlation in many studies (Kuprianova, 1967; Cronquist, 1968; Takhtajan, 1980; Karaismailoğlu 2019).

The pollen surface ornamentation is useful for delaminating some closely-related taxa belonging to various genera in the family (Khalik and Maesn Van Der, 2002; Karaismailoğlu, $2017 \mathrm{~b}, 2019)$. The coarse reticulate type of pollen ornamentation found in the studied species is in accordance with the findings of Anchev and Deneva (1997), Mutlu and Erik (2012), and Karaismailoğlu (2017b, 2019). Mutlu and Erik (2012) have informed that pollen including coarse reticulate (lumina of more than $1 \mu \mathrm{m}$ ) are generally found in humid areas unlike others, which is supported by the findings of this study.

The systematic use of anatomical features is useful in the taxonomy of the family Brassicaceae (Metcalfe and Chalk, 1957). The anatomical characteristics of the root, stem, and leaf of A. pinardii have been given in this study for the first time (Figure 4). A. pinardii cortex cells are subsequent to a thin epidermis layer in the stem which seems to be similar to the relevant images of some Alyssum, Erysimum, Aubrieta species (Orcan and Binzet, 2003; Cansaran et al., 2007; Karaismailoğlu, 2016) and Pachypragma macrophyllum (Karaismailoğlu, 2019).

Chromosome numbers in the Brassicaceae are mostly different for taxa within genera and they are important in terms of the evaluation of systematics and evolution in this family (Karaismailoğlu, 2018). Chromosome numbers of seven out of 12 species of Aubrieta in the world is known so far (Warwick and Al-Shehbaz, 2006). The chromosome counts of Aubrieta canescens subsp. canescens in Turkey reported as $2 n=16$ (Karaismailoğlu, 2016) is is consistent with our study.

\section{Acknowledgements}

We would like to thank especially Hasan Günal for his kind support and helpfulness during field studies. The specimens were collected during the field trips for a project supported by a grant from Scientific Investigation Project Coordinator of Selçuk University (Project No: 18401090).

\section{References}

Al-Shehbaz, I.A., Mutlu, B. and Dönmez, A.A. 2007. The Brassicaceae (Cruciferae) of Turkey, Updated. Turk. J Bot. 31: 327-336.

Al-Shehbaz, I.A. 2010. Brassicaceae Burnett. In: Flora of North America Editorial Committee, eds. Flora of North America north of Mexico. New York, 225, Vol. 7. 231-234.

Anchev, M. and Deneva, B. 1997. Pollen morphology of seventeen species from family Brassicaceae (Cruciferae). Phytol. Balcan. 3: 75-82.

Ančev, M and Goranova, V. 2009. Aubrieta (Brassicaceae) in the Bulgarian flora. Phytol. Balcan. 15(1): 4350.

Boissier, E. 1867. Flora orientalis, Vol. 1. Basel: H. Georg.

Bona, M. 2013. Seed-coat microsculpturing of Turkish Lepidium (Brassicaceae) and its systematic application. Turk. J Bot. 37: 662-668.

Cansaran, A., Ergen Akcin, Ö. and Kandemir N. 2007. A Study on the Morphology, Anatomy an Autecology of Erysimum amasianum Hausskn. \& Bornm. (Brassicaceae) Distributed in Central Black Sea Region (Amasya-Turkey). Int. J. Sci. Tech. 2: 13-24.

Cronquist, A. 1968. The evolution and classification of the flowering plants. Edinburgh: Thomas Nelson Ltd.

Cullen, J. 1965. Aubrieta Adans. In: Davis, P.H. (Ed.) Flora of Turkey and the East Aegean Islands, vol 1. Edinburgh University Press, Edinburgh, pp. 444-447.

Dönmez, A., Aydın, Z.U. and Koch, M.A. 2017. Aubrieta alshehbazii (Brassicaceae), a new species from Central Turkey. Phytotaxa 299(1): 103-110. 
Gabr, D.G. 2018. Significance of fruit and seed coat morphology in taxonomy and identification for some species of Brassicaceae. American J of Pl. Sci. 9: 380-402.

El-Naggar, S.M.I. 2005. Seed coat micro-sculpturing and the systematic of the Egyptian Brassicaceae (Magnoliopsida). Fl. Medit. 15: 581-598.

Güner, A., Aslan, S., Ekim, T., Vural, M. and Babaç, M.T. 2012. Türkiye bitkileri listesi (damarlı bitkiler). [A Checklist of the Flora of Turkey (Vascular Plants)]. Nezahat Gokyigit Botanik Bahcesi ve Flora Arastırmaları Dernegi Yayını, Istanbul.

Gustavsson, L.A. 1986. Aubrieta Adanson. In: Mountain Flora of Greece. Vol., A. Strid (Eds), Cambridge Univ. Press, Cambridge. pp. 268-274.

Karaismailoğlu, M.C. 2015a. Morphological and anatomical features of seeds of Turkish Romulea taxa (Iridaceae) and their taxonomic significance. Acta Bot. Croat. 74: 31-41.

Karaismailoğlu, M.C. 2015b. Morphological and anatomical features of cypsela of some Crepis taxa (Asteraceae) from Turkey and their taxonomic importance. Pak. J. Bot. 47(4): 1473-1480.

Karaismailoğlu, M.C. 2016. Addition to characters of endemic Aubrieta canescens subsp. canescens Bornm. (Brassicaceae) from Turkey. Bangladesh J Bot. 45: 509-515.

Karaismailoğlu, M.C. 2017a. Seed Mucilage Contents in Some Taxa of Aubrieta Adans. Genus (Brassicaceae) and Their Systematic Importance. Turk. J of Life Sci. 2(1): 145-148.

Karaismailoğlu, M.C. 2017b. Palynological features of eleven Aethionema taxa from Turkey and their systematic implications. Bangladesh J. Plant Taxon. 24(2): 197-204.

Karaismailoğlu, M.C. 2018. Comparison of the karyotype analyses of two Aethionema speciosum subspecies from Turkey. Caryologia 71(2): 128-132.

Karaismailoğlu, M.C. and Erol, O. 2018. Seed structure and its taxonomic implications for genus Thlaspi sensu lato sections Nomisma, Thlaspi, and Pterotropis (Brassicaceae). Turk. J. of Bot. 42: 591-609.

Karaismailoğlu, M.C. 2019. Taxonomical, morphological, palynological, anatomical and ecological investigations on monotypic genus Pachyphragma from Turkey. Pak. J. Bot. 51(3): 1021-1026.

Khalik, K. and Van der Maesn, L.J.G. 2002. Seed morphology of some tribes of Brassicaceae (Implication for taxonomy and species identification for the flora of Egypt). Blumea 47: 363-383.

Koch, M., Haubold, B. and Mitchell-Olds, T. 2001. Molecular systematics of the Cruciferae: evidence from coding plastome matK and nuclear CHS sequences. American J. of Bot. 88: 534-544.

Koch, M., Karl, R. and German, D.A. 2017. Underexplored biodiversity of Eastern Mediterranean biota: systematics and evolutionary history of the genus Aubrieta (Brassicaceae). Ann. Bot. 119: 39-57.

Koul, K.K., Nagpal, R. and Raina, S.N. 2000. Seed coat microsculpturing in Brassica and allied genera (subtribe Brassicinae, Raphaninae, Moricandiinae). Ann. Bot., 86: 385-397.

Kuprianova, A. 1967. Apertures of pollen grains and the evolution in Angiosperms. Paleobot. Palynol. 3: 7380.

Mattfield, J. 1937. The species of the genus Aubrieta Adanson. Bulletin of the Alpine Garden Society of Great Britain 7: 157-181.

Metcalfe, C.R. and Chalk, L. 1957. Anatomy of the Dicotyledons (Leaves, stem and wood in relation to taxonomy with notes on economic uses) Oxford University Press, Amen House, London. Vol. 1, pp. 7987.

Moazzeni, H., Zarre, S., Al-Shehbaz, I.A. and Mummenhoff, K. 2007. Seed coat microsculpturing and its systematic application in Isatis (Brassicaceae) and allied genera in Iran. Flora 202: 447-454.

Murley, M.R. 1951. Seeds of the Cruciferae of North Eastern America. American Middle Naturalichen 46: 18 .

Mutlu, B. and Erik, S. 2012. Pollen morphology and its taxonomic significance of the genus Arabis (Brassicaceae) in Turkey. Pl. Syst. Evol. 298: 1931-1946.

Orcan, N. and Binzet, R. 2003. The Anatomical and Palynological Properties of Alyssum obtusifolium Steven ex DC. (Brassicaceae). Turk. J. Bot. 27: 63-68.

Ozcan, M. and Akinci, N. 2019. Micromorpho-anatomical fruit characteristics and pappus features of representative Cardueae (Asteraceae) taxa: Their systematic significance. Flora 256: 16-35.

Phitos, D. 2002. Aubrieta Adanson. In: Flora Hellenica. A. Strid \& Kit Tan (Eds), A.R.G. Gantner Verlag K.G., Ruggell. Vol. 2, pp. 192-195.

Simpson, M.G. 2006. Plant Systematics. Elsevier Academic Press, London. 
Stearn, W.T. 1992. Botanical Latin, History Grammar, Syntax, Terminology and Vocabulary. David \& Charles, London.

Takhtajan, A.L. 1980. Outline of the classification of flowering plants (Magnoliophyta). Bot. Rev. 46(3): 246-248

Tekin, M., Y1lmaz, G. and Martin, E. 2013. Morphological, Anatomical and Palynological Studies on Endemic Matthiola anchoniifolia Hub.-Mor. (Brassicaceae). Not. Sci. Biol. 5(2): 163-168.

Warwick, S.I. and Al-Shehbaz, I.A. 2006. Brassicaceae: chromosome number index and database on CDRom. Pl. Syst. Evol. 259(2-4): 237-248.

Yüzbaşığlu, S., Koch, M.A., and Al-Shehbaz, I.I.A. 2015. Proof of a knowledge database concept. Aubrieta ekimii (Brassicaceae), a new species from NW Anatolia (Turkey): morphological and molecular support. Pl. Syst. Evol. 301(8): 2043-2055.

Zeng, C.H.L, Wang, J.B., Liu, A.H. and Wu, X.M. 2004. Seed coat microsculpturing changes during seed development in diploid and amphidiploid Brassica species. Ann. Bot. 93: 555-566.

(Manuscript received on 12 December 2019; revised on 16 May 2020) 